\title{
Tracing the Legacy of an Experimental Generation: Three Iconic Indian Travellers in 1890s London
}

After the First World War, most Indian students, academics, artists and religious evangels would have found ready for them in London a niche within one or another established expatriate milieu. But their predecessors, the intellectual itinerants of the 1890 s, negotiated more precarious, more solitary transSuez pilgrimages. They also enjoyed greater novelty of experience, liberality of association andprivilege of the exile-freedom to explore occult identities and ideological positions. Theirs was an experimental generation, the metropolis their laboratory. The most prominent among them, the barrister-turned-activist M.K. Gandhi, memorably subtitled his autobiography The Story of my Experiments with Truth.

Their experiments concern us because they probed what would become crucial dilemmas of postcolonial ambition: how to define India, how to negotiate its position in the wider world, and whether to parley with or parry Western culture. I aim to explore this generation by comparing Gandhi (b.1869) with two contemporary travellers to London: the Anglo-Indian author and ideologue Rudyard Kipling (b.1865), and the radical reformer and holy man Swami Vivekananda (b.1863). Although markedly different, the futures they proposed for their native country were linked by prevailing discourses and questions of common principle. Each agreed that Indian religion and Indian culture were overlapping concepts, but whether they were vehicles for individual self-realization, or for communal identity was matter for debate. Each foresaw that industrial machinery would steadily penetrate rural India, but differed as to whether it would urbanize labour and reinvigorate productivity, or rather disease the 'moral economy'. Stimulated by the strangeness of the West, their approaches to these questions discover them agreeing, and disagreeing, in often surprising ways that illuminates the history of modern India's envisaging by metropolitan exiles.

Each of these travellers networked energetically, but indepenently. They knew each other only reputation. However, the record of their journeys was a legacy that descended to the next generation of intellectual migrants, to whom they were continually present as icons or precursory exemplars. After examining each in turn, therefore, I will conclude by discussing how the 1920 s generation deliberated their own metropolitan dilemmas - now agitated by an aggressively contentious political atmosphere in India - in sympathy with or in opposition to their fin de siècle predecessors. Most significant among these was the man who had by their time attained the legendary status of Mahatma.

\section{The Saintly Barrister}

Gandhi is without doubt a figure key to the understanding of how the postcolonial Indian nation, as it emerged in the interwar years, was shaped by the circulation of travellers and ideas along lines of communication established by nineteenth-century empire. His experiences as a student in Europe (1888-1891) favoured the makings of-as his biographer Judith Brown puts it - a Victorian gentleman. But one did not have to become English to be a Victorian, and to be a 'gentleman' was to face life wearing an internationally credible persona. It is a subtle corrective to romantic notions of Gandhi as a saintly anachronism to perceive his later actions as efforts either to resist or to live up to that starched, sober and earnest identity. ${ }^{1}$ His later incarnation of Mahatma was an effort to wear no ornament other than one's humanity. But M.K. Gandhi, Barrister-at-Law, abided by the class contract that a well-starched collar should be a passport to the Empire. Not all its gatekeepers, he diligently proved, were hypocrites. During his long residency in South Africa (1893-1914), for instance, petty

\footnotetext{
${ }^{1}$ Judith Brown, 'Gandhi-a Victorian Gentleman: an Essay in Imperial Encounter', Journal of Imperial and

Commonwealth History, 27, 2 (1999), 68-85 (p.68).
} 
officials sometimes volunteered to exempt him from pernicious rules applying to 'Asiatics' or 'coolies' because they could see that he was 'a gentleman'. Such was the uniform admired by a friend at Piccadilly Circus in 1890:

He was wearing a high silk top hat burnished bright, a Gladstone collar, stiff and starched; a rather flashy tie displaying almost all the colours of the rainbow under which there was a fine striped silk shirt. $^{2}$

Although it demonstrates his punctiliousness with dress, this flamboyant outfit was not quite the later uniform of the mature professional Gandhi, but rather of the modish gadabout student bent on living up to his newfound urbanity. Such foppish affectations (as he later regarded them), which also included tuition in French, dancing and the violin, were soon curtailed by tight family pursestrings and supplanted by the more serious business of legal study. ${ }^{3}$ But Gandhi continued to vex himself with the conflict between asserting himself as a citizen of the Empire and man of the world, and safeguarding his aboriginality - 'I thus found myself between Scylla and Charybdis', as he puts it in his Autobiography. The vows to abjure meat, liquor and women that he had adopted originally for the sake of maternal affection now demarcated his cultural praxis. ${ }^{4}$ Given that so many of his associates there were nonconforming Christians, it is apposite that his memoirs of England somewhat resemble the moral meanderings of The Pilgrim's Progress, with many often well-meaning tempters both British and Indian proffering the tainted luxuries of Vanity Fair (typically roast beef).

The moral armour of temperance, rectitude and piety with which Gandhi met these threats was characteristic of the evangelical earnestness that marked companions like the journalist Josiah Oldfield. But in Gandhi's case, the imperative for self-possession also supported a dimly-sensed burden of cultural loyalty and authenticity. After 1906 this would be supplemented by brahmacharya vows of strict renunciation, his ethical lineaments corresponding to new outward garments of simple Indian cloth. With the later arrival of newsreel, global media audiences would find this unworldly sanctity compelling, but particularly because the ever playful and dandyish Gandhi knew how to blend into his exotic persona gestures of striking familiarity. Cinema-goers found him reminiscent of Mickey Mouse or - with more political nuance - the socialist Charlie Chaplin whom he met in East London in 1931. To the religiously-minded, meanwhile, he recalled benevolent Christian mendicants like St Francis. But, crucially, it was the lawyerly 1890s that made possible this iconic Mahatma of the Salt March, who intrigued journalists with a fastidious gait acquired in Piccadilly, and solicited pious sympathies with a robust, abstemious constitution earned tramping between late Victorian London's distant enclaves of idealistic, apostolic vegetarians.

\footnotetext{
${ }^{2}$ S. Sinha, quoted in Brown, 'Gandhi', p.71.

${ }^{3}$ M.K. Gandhi, The Collected Works of Mahatma Gandhi, 100 vols (Delhi: Government of India, 1958),

XXXIX, 46-48 [henceforward $C W M G$ ].

${ }^{4} C W M G$, XXXIX, 42.
} 


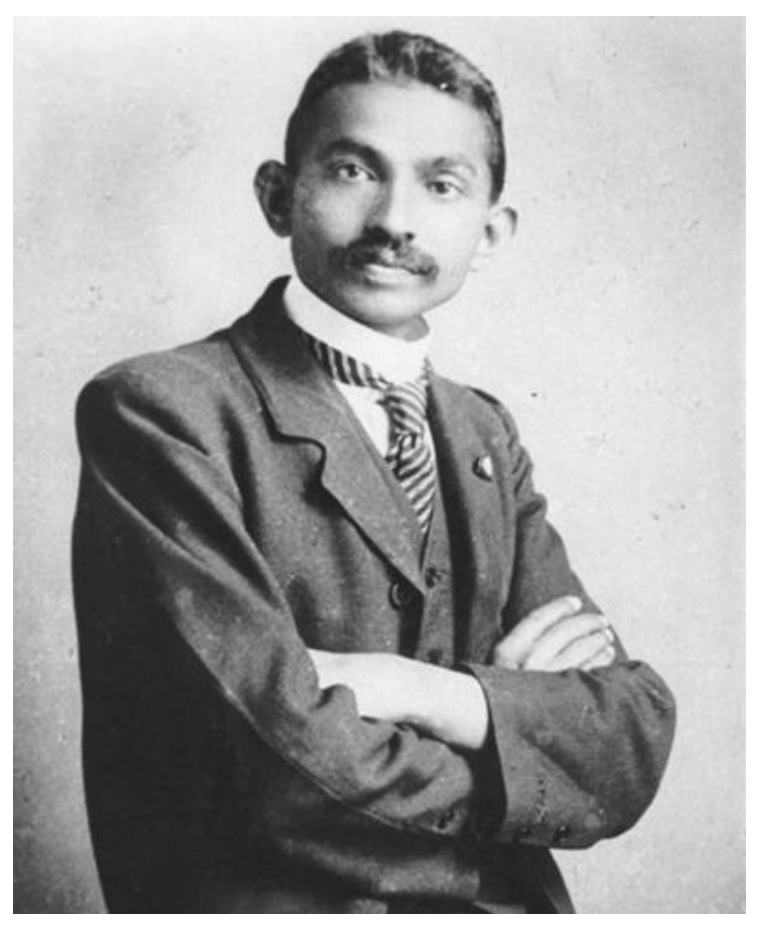

Gandhi in professional dress, 1904, wearing the badge of the London Vegetarian Society

Gandhi's famous quip that Western civilization would be a very good idea was several decades away. But the notion that insanitary and criminal modern cities were stunting the moral, physical and spiritual growth of their overburdened inmates would have been topical in the intellectual circles within which Gandhi was moving, such as the anti-vivisectionist Humanitarian League. Stephen Hay has speculated that here Gandhi would have discussed the dignity of physical labour and selfsustaining rural living with Edward Carpenter. The poet radical's 1889 Civilization: its Cause and Cure is listed among the recommended reading appended to Gandhi's seminal pamphlet Hind Swaraj, along with John Ruskin's straight-backed denunciation of political economy Unto this Last. While Gandhi as an activist made repeated visits to London (in 1906, 1909, 1914 and 1931) to petition officials and further his political liaisons, philosophically he came to altogether reject metropolitan life. ${ }^{5}$ Written on his return voyage to South Africa in 1909, Hind Swaraj expounded Gandhi's mature conviction that the West was 'half-crazed' by the lure of material gain. When he completed his studies and left London for India in June 1891 these views were still in gestation, but the encounter with Carpenter may have informed the parting interview published by his journalist friends. Questioned about his original journey to London in September 1888, Gandhi recalls his zeal to dwell within 'the land of philosophers and poets, the very centre of civilization', but swiftly qualifies these boyish aspirations - 'they by no means represent my present views'. ${ }^{6}$

Gandhi's opinions were not inculcated by metropolitan society. Rather they emerged gradually from his unguided explorations, and the intellectual seeds that would grow into scathing critiques were sown haphazard amidst busy participation in what he found to be a multifaceted heterodoxy. Though Gandhi had aspired to inhabit the 'centre of civilization', once there he discovered that the philosophers and poets were seeking to effect change upon a bourgeois establishment from a

\footnotetext{
${ }^{5}$ His experiences on these visits are detailed in James D. Hunt, Gandhi in London (Delhi: Promilla, 1978)

${ }^{6}$ Stephen Hay, 'The Making of a Late-Victorian Hindu: M.K. Gandhi in London, 1888-1891', Victorian

Studies, 33, 1 (1989), 74-98 (p.93); Brown, 'Gandhi', p.82; CWMG, I, 54.
} 
countercultural fringe. Frequenting the social fora provided for Indian students, such as the Northbrook Society reading room in Doughty Street or the lectures by Indian MPs such as Dadabhai Naoroji and M.M. Bhownagree arranged by the National Indian Association, would have led one swiftly in those days into contact with Theosophists. With chapters across the world, the stature of this esoteric congregation was rising - their future leader Annie Besant joined in 1889, and in the same year two members approached Gandhi under the misapprehension that he would know Sanskrit. This led him to his first, seminal reading of the Bhagavad Gita as rendered in Sir Edwin Arnold's popular translation The Song Celestial. Reading late at night in his rented lodgings, Gandhi famously attempted to synthesize the lessons of the Gita, the Sermon on the Mount and Arnold's Buddhistic epic The Light of Asia. It was an exercise befitting the liminal space which he was now beginning to discover within the metropolis, where political, religious and cultural affiliations persistently overlapped. ${ }^{7}$

Diet was Gandhi's entrée to this space and to personalities such as Arnold. Finding that the former Pune professor and Daily Telegraph editor now lived nearby in Bayswater, he invited him to serve as Vice-President of the local vegetarian club he had established with Oldfield, now his housemate. ${ }^{8}$ The subculture of vegetarian restaurants and journals to which Oldfield introduced him provided Gandhi with object lessons in organization and campaigning. Moreover, the Vegetarian Society on whose executive he served from 1890 was no longer just a blue-ribbon nanny of factory labour but a haven for various eccentric renegades of the 'late Victorian revolt'. A broad trend embracing dissent from both class and gender norms and from conventional politics, this would have included Fabian socialists like G.B. Shaw, along with spiritual renascents and Irish nationalists such as Annie Besant and W.B. Yeats - radicals exploring a constellation of enchained orbits, but broadly shunning the prevailing orthodoxy of liberal economics and imperial militancy. ${ }^{9}$ Edited by Oldfield and enjoying a bohemian circulation, its organ The Vegetarian dwelt frequently on themes that would occupy Gandhi throughout his South African years. Ruskinian environmentalism and praise of honest agricultural labour over the degraded, cannibal life of the city was a prominent credo, and Gandhi's scrutiny of the violence inherent to industrial civilization would be deepened by his later reading of Tolstoy and of Thoreau's 'Civil Disobedience'. The latter pair's construing of modern society as an economic device that systematically automates its human agents informed the doomladen prognoses for English society that characterized Hind Swaraj. 'Unless its whole machinery is thrown overboard,' he wrote in 1909, 'people will destroy themselves like so many moths'. ${ }^{10}$

As the shipboard composition of Hind Swaraj suggests, reading as well as diet were conduits for international coalition, and Gandhi's encounters with influential texts were intrinsic to his personal networking. This pattern continued when his vegetarian activities in London gave him an entrée to affiliated clubs and restaurants in South Africa. Here he met Henry Polak, who shared his moralistic social critique and puritanical, autarkic personal standpoint. The modern tracts which appealed to men like Polak, and which they consequently recommended to Gandhi, were those that bestowed the burden of civilization upon individual virtue, and which were often preoccupied with masculine physicality and firmness. This emphasis on self-discovery made for a practically flawed but personally revelatory brand of politics, governed not by utilitarian expediency but by the demands of private conscience. If in London, as Hay proposes, Gandhi admired Gladstone's manner of infusing

\footnotetext{
${ }^{7} C W M G$, XXXIX, 53, 61.

${ }^{8}$ Ibid., 60.

${ }^{9}$ Ibid., 67; James Gregory, Of Victorians and Vegetarians: the vegetarian movement in nineteenth-century
}

Britain (London: Tauris, 2007), pp.65-67.

${ }^{10}$ Henry Thoreau, Walden, Civil Disobedience and other writings, ed. by W.J. Rossi, $3{ }^{\text {rd }}$ edn (New

York: Norton, 2008), p.234; $C W M G$, IX, 389. 
parliamentary politics with morality, then Thoreau deinstitutionalized this habit by making the individual soul the crucible in which social crisis was resolved by private action, man segregating the satanic from the godly within himself. ${ }^{11}$ The salvational rhetoric of Unto this Last, moreover, anticipated one of Gandhi's most quoted dictums by infusing religion with politics.

With the help of friends like Oldfield and Polak, the political discourse Gandhi began to evolve was characterized therefore by an ethical absolutism. The pages of The Vegetarian reveal this discourse in development, often coalescing around the capitalized enigma that Gandhi made his medallion. 'The Discovery of Truth, the diffusion of Truth, and the Application of Truth to the Welfare of Humanity,' was James Burns's definition of 'Spiritual Science' in October 1889, while another contributor signed himself simply 'Truth'.

On reflection, 'Truth' has a unilateral, unbending character that makes it an odd concept for a lawyer and politician to frame. But it is also a vague catch-all, and in this mixture of orthodoxy and heterodoxy lay its appeal. For truth may denote a correct, singular and divine goal distinct from diffuse mortal delusion, but the crooked paths that men may take to reach that goal are myriad. This is where the cosmopolitan nature, as well as doctrinal inclusiveness, of Gandhi's politics emerges: everyone pursues their own experiments with truth, but once enlightened the individual joins a global community of initiates. Hence ethical absolutism translates into ethical universalism. 'All Men are Brothers' was a Gandhian maxim that gestured toward the globalized spiritual brotherhood which, once popularized by Theosophy, became a shibboleth of trans-Suez pilgrims for the next twenty years. As Oldfield had put it in a Vegetarian editorial of late 1889, 'This is the last chord of Christian civilization. It begins with the individual and ends with the Common Weal'. ${ }^{12}$

\section{The Aesthetic Imperialist}

Truth was to become an all-embracing concept for Gandhi: the criterion both of individual righteousness, cultural authenticity and national maturity. Reverently capitalized, it is also a word deployed frequently and somewhat cryptically by Rudyard Kipling - 'so much true; so much new' was how India struck his writer's eye in the mid-1880s. ${ }^{13}$ Kipling's preoccupation with the word is too complex to explore here in full, but it indicates for us three important points of similarity with Gandhi. Firstly, it suggests that the worldwide fraternity - in his case, an imperial collective-which Kipling attempted to politically orchestrate was also predicated on individual self-realization. Secondly, 'Truth' was the antidote to a malaise of illusion and confusion endemic to modern, globalized life: Kipling too was concerned with how the individual mind should imaginatively —or, in Gandhian terms, spiritually - comprehend a world of speedy interconnection and baffling relativity. Thirdly, this quality of Truth existed in high concentration in India, especially non-urban India, whereas the headwaters of delusion flowed from the Western metropole. Bearing this verbal link in mind, the extent of Gandhi and Kipling's mutuality can be tested by linking them through several common discourses that were brought to the fore during their concurrent residences in London.

Although he was returning 'Home' in Anglo-Indian argot, it is in many ways more productive to view the writer who arrived in the imperial metropolis eleven months after Gandhi as another colonial, intellectual migrant. Born at Bombay in 1865, Kipling had just concluded 'seven years' hard' as a north Indian journalist with several acrimonious libels on first-generation Congresswallahs. Despite this hostility-and his ardent devotion to steam, steel and soldiers-many affinities can be drawn between Gandhi and this 'native-born' Anglo-Indian negotiating his own somewhat troubled pilgrimage to the mother country. Gandhi would later counsel a younger generation of London migrants (most notably the Labour politician and activist Krishna Menon) in propagandising Indian nationalism to the British Left. Though imperialist in design, Kipling's ambition in London was of the

\footnotetext{
${ }^{11}$ Hay, 'The Making', p.94.

12 ibid., pp.91-92.

${ }^{13}$ The Letters of Rudyard Kipling, ed. by Thomas Pinney, 6 vols (London: Macmillan, 1990-2004).
} 
same pluralist scope: to inspire a recalcitrant and insular British public with a sense of global mission. Moreover, it was a strategy of each, repeated in several countries, to infiltrate established politics from a marginal position. If Gandhi would later enter the Congress as an expatriate wildcard, then in England Kipling too possessed the assets of the 'critical outsider'. ${ }^{14}$ Disrupting parochial dispensations, both sought to induce inflexible mindsets to realize worldly, universal standards of citizenship, responsibility and 'Truth.'

Their mutual critiques of India frequently evince the same stern pragmatism of the disciplinarian Victorian reformer. Urban hygiene was a pet peeve of both men. Gandhi served zealously on a sanitation committee during a home visit to Rajkot in 1896, while what might be regarded as Kipling's offensive denigration of Benares in his story 'The Bride's Progress' was resoundingly echoed by the Gujarati on his first visit to Hinduism's holiest shrine: 'The approach was through a narrow and slippery lane. Quiet there was none. The swarming flies and the noise made by the shopkeepers and pilgrims were perfectly insufferable'. ${ }^{15}$ Decisive intervention was required to rectify these ills, to be executed not by corrupt and compromised democratic procedure but by hardworking moral exemplars such as those extolled in Heroes and Hero-Worship. Gandhi eagerly devoured Carlyle's essay in London, while Kipling's guardians had personally known the Scottish historian. The value set on clear sight and 'true talk' by such a fabular mindset is one of the abiding ironies of Kipling's work. But both the devotee of satya [truth] and the celebrant of 'the Dreamer whose dream came true' expressed their attraction to concrete things in a revelatory way-it was woolly mysticism that disinclined both men to Theosophy, in spite of Gandhi's personal esteem for Annie Besant. ${ }^{16}$

Like Gandhi, Kipling had promised himself the urbane lifestyle of a Piccadilly flaneur, but he found the foggy metropolis not to his liking. Ironically, he had planned his journey 'Home' with an eye to establishing himself as a man of the world, using his first royalties to globetrot the long way round to London and observe both 'cities and men' from Burma to Japan and North America. He undertook this formative voyage, as of course did Gandhi, at a germinal political moment. Britain's financial dominion in the East was being progressively infringed at this time by American and Japanese interests, while her colonial overlordship was menaced by such widespread developments as the foundation of the Indian National Congress (in 1884) and the Land War in Ireland. Kipling belonged to a generation of neo-imperialists who sought to insulate the Empire with commercial tariffs and to propagandise a regnant consciousness at home. It was from this circumnavigatory journey that the poet's mature, global vision of Anglo-Saxon imperium can be seen to emerge, yet its culmination was muted by wistful disquiet. Culture shock and homesickness for India troubled him persistently, while arrival in the so-called 'centre of civilization' left him totally unmoved. To him London was a place of drab, monochrome uniformity, peopled by 'savages living in black houses and ignorant of everything beyond the Channel'. ${ }^{17} \mathrm{He}$ spasmodically retreated into his India-born identity, a reaction more precipitate than Gandhi's and made explicit by the 1889 poem 'In Partibus', in which he utterly dismisses the formless, irrational and alien city with a Hindi word.

The buses run to Islington,

To Highgate and Soho...

But I can only murmur 'Bus!' [enough]

From Shepherd's Bush to Bow. ${ }^{18}$

\footnotetext{
${ }^{14}$ Brown, 'Gandhi', p.78.

${ }^{16} C W M G$, XXXIX, 61, 197; CWRK, XXI, 362.

${ }^{17}$ Kipling, Letters, I, 348.

${ }^{18}$ CWRK, XXXV, 176.
}

${ }^{15}$ CWMG, XXXIX, 139, 195; Rudyard Kipling, The Sussex Edition of the Complete Works in Prose and Verse of Rudyard Kipling, 35 vols (London: Macmillan, 1937-1939), XXIII, 432 [henceforward CWRK]. 
The unfavourable contrast implied between Eastern harmony and Western discord was a theme to which Kipling was warming in his travel sketches. Shocked by the 'grotesque ferocity' of Chicago, he had appealed to his home readership with a nostalgic sketch of orderly and humane life in the idealized Punjabi village of Isser Jang. Kipling's own poetic evocations of the iniquitous hardship of rural life give the lie to this romantic ménage of changar, lohar, barber and money-lender, but two years later Gandhi was to employ similar Ruskinian imagery in his description of Diwali morning for The Vegetarian.

You are standing near the corner of a public road. Mark the shepherd trotting onward in his milk-white suit ... singing some broken verses... Soon after you see a crowd of little maids, with small earthen vessels resting on cushions placed on their heads... Then observe that big man with white whiskers and a big white turban... He, you must know, is a great banker. ${ }^{19}$

As the anthropologist M.N. Srinivas has remarked, Gandhi often comes close to echoing the idyllicanarchic conception of Indian villages as 'little republics' popularized by British officials like Munro and Metcalfe. Moreover, his location of social unity in a country fair echoes the rustic 'river of life' envisaged by his fellow townsman in Kim. ${ }^{20}$

Gandhi and Kipling - figures we might call urban refugees - have recourse therefore to exaggerated reveries of parochial origin. But the full implications of their romanticism were far from insular. Having discovered a common enemy in the erosive homogeneity of late imperial global capitalism, they were both attempting to devise an authentic cultural vision of a unified subcontinent so that their native country might assume its legitimate position within the world. But this necessitated a delicate negotiation between aboriginality and cosmopolitanism that for Kipling was always bound to be vexed. The Empire's ideological coherence would be safeguarded, he decided, by a sympathetic fraternity of 'native-born' colonials like himself. These would, in turn, reform and reverse imperial decadence within the metropole. Such men were, like their brown-skinned peer M.K. Gandhi, cultural hybrids. But to legitimate the former with the mantle of native authenticity required that the latter be denigrated as an ersatz mimic. If Kipling, in fact, ever crossed paths with the young barrister under the railway arches separating his Villiers Street lodgings from the Indian National Congress offices in adjacent Craven Street, he would have seen a despicable frock-coated 'babu'. To such prodigals, his chosen protagonist for 1890's 'One View of the Question' was intended as a riposte. The story is framed as a letter dispatched from the Northbrook Club by the envoy of a princely state. The haughty Muslim nobleman condemns London and its inhabitants for their drunkenness, avarice and vulgarity, and by extension damns metropolitan England itself as emasculated and feeble. ${ }^{21}$ The implication is not only that English manhood and government requires an injection of native-born vigour, but also that India will supply the cultural integrity and social order which is chaotically dissipating in the ruling nation. As an 1890s social critique voiced from a position of oriental authenticity, it also reveals the extremity and vulnerability of Kipling's position: Britain is not just economically, but also culturally dependent on its colony.

If India was 'truly' to be Britain's antithesis and better half, this necessitated its pristine insulation from the deleterious influence of global capitalism and concomitant social change. Gandhi is susceptible to similar charges of conservative, paternalist romanticism, and of resenting culturolinguistic hybridity — his derogation of Portuguese liner stewards who 'murdered the Queen's English'

${ }^{19}$ CWRK, XXIII, 150-151; CWMG, I, 39-40.

${ }^{20}$ M.N. Srinivas, 'The Indian Village: Myth and Reality', in The Village in India, ed. by Vandana Madan

(Delhi: Oxford University Press, 2002), p.52.

${ }^{21}$ CWRK, V, 81-101. 
is just as snooty as any of Kipling's dismissals of sallow hybrids oiling the global labour market. ${ }^{22}$ But the ability to shift his ground and stretch his identity underscored Gandhi's political ascendancy. Where Gandhi could filter what he chose from European culture, Kipling could not help but fall back on essentialism. His imaginative coups occur when he brings the two cultures into mutuality through liminal, translating figures, who are typically either silver-tongued vagrants like Kim or holy mendicants like his Lama companion. Interestingly, these figures often anticipate Gandhi's own Mahatma persona. Upon meeting him his first biographer Joseph Doke was irresistibly reminded of Kipling's Purun Bhagat, like Gandhi a bania turned ascetic St Francis figure. ${ }^{23}$ Strangely, Kipling completely failed to recognize the parallels when Gandhi literally came to carry the pilgrim's staff onto cinema screens across the world. In his final years he replied to the dinner-table question "was Gandhi sincere?" by declaring that the Mahatma's political act was just 'a paste-board front'. ${ }^{24}$ The implication was that he, the would-be European vairagi, was sincere in his identity while colonial nationalism was only the misbegotten offspring of rotten Western polities. But while Kipling clung rigidly to essentialist classifications, the most successful of the 1890s ideologues were those, like Gandhi, who could adapt and communicate along culturally bilingual lines: personating, as on the Salt March, both holy sage and Chaplin's Tramp. His quiet victory over Kipling, whom he read extensively during his South African imprisonment, lay in interpreting the Anglo-Indian to speak to his own more plural point of view. 'His writings, to my mind, have been very much misunderstood,' Gandhi remarked during a 1908 speech. 'With extended experience, [he has] revised his views, and he no longer thinks ... that the white man may not co-exist with the Coloured man. ${ }^{25}$

\section{The Cyclonic Swami}

If significant mutuality can be detected between the arch-imperialist and the freedom-fighter, it must be remembered that alternative schools of nationalist thought were also developing within the 1890s metropolis, promulgated by their own iconic pioneers. Among this speculative and itinerant generation one man stands out as an unfettered risk-taker. Unlike Gandhi and Kipling, my third casestudy is someone the historian hesitates to call a man of his time, and this makes him a useful, antithetical figure to read against established narratives. As with his two contemporaries, migration to the Western metropolis enabled both the philosophy and the fame of Swami Vivekananda. But what they came to reject, he continued to embrace. Furthermore, if they believed essentially in resisting deculturing global economic forces from the stronghold of the individual conscience, then he hoped to channel those forces to revolutionize society collectively, from the outside, and in thoroughly material terms. A proponent of technology and incendiary politics, adding him to the discursive comparison reveals Gandhi and Kipling's limitations. For while Vivekananda was a somewhat eccentric figure in his time, in many ways his legacy has been the most enduring.

He began life Narendranath Dutt, a Bengali seminarian and reformer who absorbed a detestation of 'priestcraft' from Herbert Spencer, and from his Calcuttan guru Sri Ramakrishna the conviction that the world's religions and sciences would ultimately attain integration within nondualist spirituality. ${ }^{26}$ Embracing otherness after the manner of Kipling's vagrant heroes, Dutt undertook a pan-Indian pilgrimage in 1891 and adopted the nom de guerre Swami Vivekananda. Two years later his addresses

\footnotetext{
${ }^{22} C W M G, \mathrm{I}, 65$.

${ }^{23}$ Joseph Doke, M.K. Gandhi: an Indian Patriot in South Africa (London: London Indian Chronicle, 1909),

p.92.

${ }^{24}$ Lord Frederick Birkenhead, Rudyard Kipling (New York: Random House, 1978), p.340.

${ }^{25}$ CWMG, XXIII, 147-148, 179; VIII, 243.

${ }^{26}$ Amiya Sen, Swami Vivekananda (Delhi: Oxford University Press, 2000), pp.21, 53.
} 
to the World's Parliament of Religions in Chicago achieved global celebrity. Now a star performer, he spent much of what remained of his brief life proselytizing in North America and Europe, visiting London (1895, 1896 and 1899) and Paris repeatedly. With time Gandhi grew to regard Western travel as merely a necessary evil, whereas the Swami possibly hastened his early death by a tireless quest for novel vistas. As for Kipling, travel constituted a mapping exercise, the sketching of a world vision. But his wholehearted commitment to the world in fact outstripped the Anglo-Indian's (necessarily) semi-parochial viewpoint. Steaming from India to Chicago in 1893, Vivekananda followed an itinerary almost identical to Kipling's four years beforehand, but the apparition of industrious modernity in ancient China and Japan filled him with enthusiasm rather than disquiet. ${ }^{27}$

Vivekananda's experiences abroad led him to some highly idiosyncratic positions. Where his concerns overlap with Kipling and Gandhi's shared discourses, we find him energetically pushing their suppositions to their logical extremes. Masculine self-sufficiency, for example, became with him an obsession for physical fitness and vigour. Moreover, he extended their preference for decisive leadership over conventional bureaucratic government to a bitter distrust of all constitutional politics. Those arguments that he did not amplify he boldly reversed, especially where they concerned India's relationship with modernity. The letters from the West he addressed to his Indian supporters embrace a whole field of radical ideas orbiting the fiery particle of his being: feminism, electromagnetism, socialism, social Darwinism. His openness to metropolitan technology and legislation is marked by an attitude of cultural relativism and pragmatic, even hard-nosed, exchange. 'I give them spirituality, and they give me money', is the burden of a Bengali remark in one of his engagingly frank letters, most of which are written in rather fast and natty English - he urges his colleagues, for example, to recruit men with 'with go!'28

The Gandhi of the mid-90s was increasingly distressed by the inherent violence of the West's frantic social mechanism. But for Vivekananda, imperialism was an engine devised by history to smash India's 'crystallized' society. He suggests that caste will be eliminated by modern labour competition. A clean and efficient female reformatory garners his utilitarian approbation. "Work" almost becomes his equivalent of "Truth", and the world's accelerative interconnection promises not spiritual withering but intellectual revolution. His recurring visits to London were inspired he says by the belief that 'this British Empire with all its drawbacks is the greatest machine that ever existed for the dissemination of ideas. I mean to put my ideas at the centre of this machine, and they will spread all over the world. ${ }^{29}$

\footnotetext{
${ }^{27}$ The Complete Works of Swami Vivekananda, 8 vols (Calcutta: Advaita Ashrama, 1991-1992), V, 6-10

[henceforward CWSV].

${ }^{28}$ CWSV, VI, 255.

${ }^{29} \mathrm{CWSV}, \mathrm{V}, 11,23,13$; VI, 365-366
} 


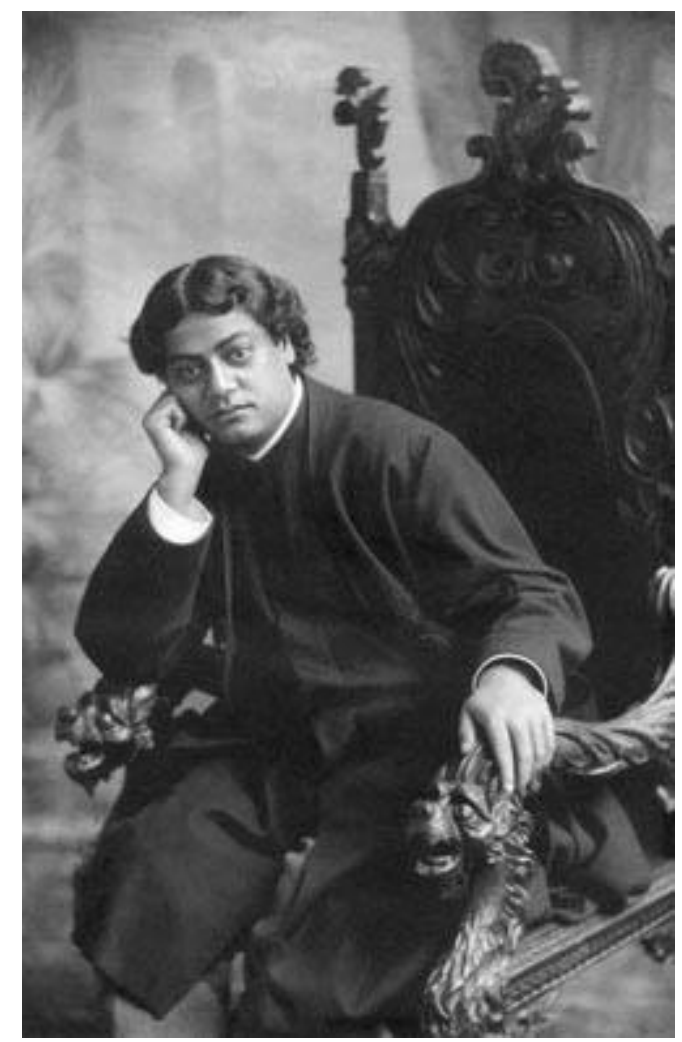

Swami Vivekananda in San Francisco, 1900

Coeval with this embrace of the urban and modern was a fervent disregard for provincialism and historical romanticism, and the 'awful mass of conservative jelly-fish' that inhabited "village republics" like Kipling's Isser Jang. 'I like to see new things,' he declared. 'I do not care a fig to loaf about old ruins and mope a life out about old histories and keep sighing about the ancients. ${ }^{30}$ In contrast to what might be called the protectionist policy of Gandhi and Kipling therfore, Vivekananda is eager to open India up to international traffic. His transoceanic voyages were a conscious attempt to facilitate this exchange: bringing India to the world, and the world to India. While Indian thought was, he maintained, overly introspective, 'the backbone of Western civilization is-expansion and expression', and he urged young reformers to undertake world tours as vehemently as he ordered his monastic brethren to teach geography, science and photography in Gandhi's hallowed villages. 'To become broad, to go out, to amalgamate, to universalize, is the end of our aims' ${ }^{31}$

What emerged from this intellectual velocity was a synthesis of East and West more volatile, catalytic and prescriptive than Gandhi's confessional grafting of Gita to Bible. 'Yoga, knowledge, devotion and work'-its regimented phrasing betrays Vivekananda's emphasis on material change from outside the social structure. ${ }^{32}$ The political solutions derived from this maxim emerged, as with Gandhi and Kipling, from his encounter with the metropole, but their enduring radicalism ensured for Vivekananda a sinister, conflicted afterlife. Like Gandhi, in the West he preached spiritual selfrealization to counter the ill-effects of economic atomization. But the caste inequalities associated with religion in India must, he insisted, be tackled with collective, cultural renovation. 'Our national

\footnotetext{
${ }^{30}$ CWSV, VII, 498.

${ }^{31}$ CWSV, III, 441; VI, 289; III, 271.

${ }^{32}$ CWSV, VII, 496.
} 
life is in our religion... You are bound by it, and if you give it up, you are smashed to pieces,' he told one lecture audience. 'It is culture that withstands shocks,' for (adopting a disciplinary, Kiplingesque tone) 'knowledge is only skin-deep, as civilization is, and a little scratch brings out the old savage'.33

This position necessitated that Hinduism be 'cleansed' of its variant sects, and rendered Vivekananda indifferent to reformist agendas such as widow remarriage. In his last years it prompted one of his most classically vexed distinctions. ${ }^{34}$ India was the reverse of the West, in that its religious thought was particular to the believer whereas its social life was communistic. Consequently he embraced socialism, since in the coming proletarian upsurge forecast by Prince Kropotkin (Vivekananda met the celebrity anarchist in Paris) contemporary India-already 'socialized' by its caste system - would achieve social levelling non-violently. ${ }^{35}$ But this was only the Swami at his most optimistically tranquil, for many of his pronouncements uneasily foreshadow the bitter conflicts that racked the century he never lived to see. In the 1920s, when the struggle for self-definition pioneered by the 1890s generation gave way to bloody identitarian feuds, Romain Rolland observed that Hindu mobs would fire themselves with Vivekananda's name in disturbing contradiction of their guru's ostensible non-violence. 'His faith burns while Gandhi's shines', the French orientalist commented, even to the point of his 'revolutionary individualism' unintentionally inspiring 'social incendiarism. ${ }^{36}$

The Swami's influence should not be sidelined by his more famous peers. His example may be posited as an antithesis to that of Gandhi or Kipling, demonstrating that exilic envisagings of the new India could be much less culturally defensive and romantic. As such he serves as a link to the succeeding generation by gesturing towards such future possibilities as international socialist alliances, the Nehruvian commitment to a technological renaissance and, arguably, the insurgent militancy of Subhas Chandra Bose or assimilationist Hindu nationalism of recent years. His enthusiastic prophecy of radical social change makes him in many ways a more apt forerunner for contemporary India, even though these changes have arrived through the dynamic outcomes of market forces rather than the preceding decades of regulatory state socialism. Moreover, whereas Kipling and Gandhi so carefully negotiated the space between their Eastern and Western identities, he was determined to fuse them - a most combustive experiment that left him in a state of continental schizophrenia, but that now offers us a foreshadowing of what we would term multicultural codeswitching. 'From Suez begins Asia. Once more Asia', he wrote to an English friend in 1897 during one of his frequent ocean passages. 'What am I? Asiatic, European, or American? I feel a curious medley of personalities in me. ${ }^{37}$

\section{Legacies: the Interwar Generation}

Vivekananda's disorientation exemplifies the migratory experience, passionate but also confused, of the 1890s travellers. In the 1920s and 1930s, the influential but inchoate data accrued by their experimental lives would be used to frame formulae for postcolonial societies. Models and principles were now debated by a vastly increased academic population (by 1927 British institutions housed

\footnotetext{
${ }^{33}$ CWSV, III, 289-291.

34 ibid., 286-288; V, 29.

${ }^{35}$ CWSV, IV, 467-470; VIII, 269.

${ }^{36}$ Romain Rolland, The Life of Vivekananda and the Universal Gospel: a study of mysticism and action in living
}

India, trans. by E.F. Malcolm-Smith (Calcutta: Advaita Ashrama, 1984), p.327.

${ }^{37}$ CWSV, VIII, 395. 
approximately 1700 Indian students). ${ }^{38}$ It was a charged atmosphere in which the ideological standpoints tried out by the 1890s pioneers had, for the new generation, become entrenched political alignments. Moreover, the pioneers who originally tested those standpoints became icons for their propagation - or effigies for their abolition. The burden of managing one's various political affiliations - the legacy of an experimental life - and fronting a united resistance to colonial rule weighed heavily on the leader now internationally known as Mahatma.

There was a further polarizing factor. What Gandhi had adjudged modern civilization was now partitioned between capitalist and Soviet spheres, each espousing political philosophies of global embrace. A broad new avenue had thus opened for the formation of radical networks. a development which is amply attested by contemporary police surveillance reports housed in the India Office Records. Whether speculating on the alliances forged during Jawaharlal Nehru's visit to Moscow in 1927, or noting drily that his friend and facilitator Krishna Menon was using his position as a Labour councillor to rally donations for republican Spain, these intelligence documents seem ponderous with the suspicion that worldwide political momentum had been lost to colonial nationalists and their leftist accomplices. ${ }^{39}$ Kipling's rather paranoid letters of the time exhibit the same incertitude, their skittish, insular position marking a painful retreat from the global role he had long advocated for Britain. ${ }^{40}$

When M.K. Gandhi returned to London in 1931 after a seventeen year absence, his public persona was at the height of its mobilizing potential. In 1888 he had stepped ashore in chilly October sporting comical white flannels. Now he took his seat at the second Round Table Conference dressed in startling white khadi. But he, and the 1890s legacy he represented, proved as much an object of controversy as of adoration. The conference failed to reach a legal resolution on Indian self-rule after Muslim and Untouchable delegates denied Gandhi's claim to legitimately represent their interest. Moreover, leftists accused him of betraying his peasant constituency to the Congress's moneyed patrons. His public appearances in London were dogged by hecklers, presumably sent by the Communist MP Shapurji Saklatvala, who marred his $62^{\text {nd }}$ birthday celebrations with cries of 'Down with Gandhi', 'Kill Gandhi' and 'Agent-provocateur of the British Government'. ${ }^{41}$

The novelist and social critic Mulk Raj Anand (b.1905) is perhaps representative of the young turks whose veneration for the Mahatma was tinged with nagging dissatisfaction. Among those students who answered Gandhi's summons - and were duly arrested - during the Non-Cooperation Movement (1920-22), Anand had come to UCL in 1925 to write a doctoral thesis in philosophy. The diaries and letters from this period, novelized as The Bubble, reflect a concerted effort to define his own position in an increasingly disputatious climate. Gandhi, whom he frequently heard criticized for the turbulence of Non-Cooperation and successive campaigns, became a locus for Anand's swallowed pride. He fondly remembers poring over Gandhi's latest editorials in Young India at Menon's India League office in the Strand. Here was a migrant who had not merely conquered the metropolis, but had rejected it. You look 'like a monkey' Anand remembered him saying when he visited Gandhi's ashram in the late 1920s wearing a brown corduroy suit, an experience which provoked Anand's own

\footnotetext{
${ }^{38}$ A.K. Singh, Indian Students in Britain: a Survey of their Adjustment and Attitudes (Bombay: Asia Publishing House, c1963), p.21.

${ }^{39}$ London, British Library, India Office Records (IOR), L/PJ/12/292, p.12, 26; L/PJ/12/323, pp.21-23.

${ }^{40}$ Kipling, Letters, VI, 214.

${ }^{41} \mathrm{IOR} / \mathrm{L} / \mathrm{PJ} / 12 / 235$, p.20.
} 
conscious withdrawal from what he felt to be an enthralled tutelage to Bloomsbury modes of dress, speech and thought. ${ }^{42}$

Mahatma Gandhi was not the only 1890s icon weighing on Anand's mind. He harboured a deep resentment of his loyalist father and other conservative 'elders'. Kipling (also the product of an armydominated Punjabi milieu) was an obvious target for such counter-thrusts as Coolie. Anand conceived this realist novel of impoverished boyhood in reaction to the fantastic 'Truth' of Kim, determining to vanquish the Anglo-Indian's imaginative hegemony. ${ }^{43}$ But Gandhi too, if a onetime mentor, was a flawed patriarch. Although at the ashram Gandhi had stimulated his appreciation of the division of labour by having him scrub out the latrines, it was just this sort of summons to private virtue that indicated why the Victorian follower of Ruskin, immersed in the village republic, could never embrace socialism as a political system. Craving broader means of societal rehabilitation, Anand was inclined instead to resist imperial capitalism through confederation with the alternative universalism proffered by Soviet Russia. Stalin's planned state promised the futuristic overhaul of impoverished societies, and the hardheaded rejection of a compensating romanticized past.

The Soviet model was Vivekanandan in its external radicalism and disregard for tradition or the individual will. Anand deploys the Swami in aptly antithetical mode at the dénouement of his first novel Untouchable (while pompous Congresswallahs debate a speech of Gandhi's, the title sweeper awaits revolution-by-technology - the flush toilet). ${ }^{44}$ But Anand's mature agenda was more temperate. Anand maps out his political position cogently in the controversial Letters on India of 1942, illustrating with incisive Marxist dialectic how 'India has been made into a suburb of London, New York or Chicago, politically, economically and culturally.' He briefly evokes the epic interligature of telegraphy, finance and railway so extolled by Kipling, before revealing that instead of Vivekananda's 'expansion and expression' it has brought about only 'constipation.' For the current of history to be unclogged and world markets to be truly globalized, imperialism as an economically provincializing force must be eliminated. ${ }^{45}$

Composed in a besieged city at the height of global struggle, Letters on India is a thoroughly worldly text, a pragmatic appraisal of two economic systems that Gandhi would have dismissed as equally godless and mechanical. Casting a baleful wartime eye on the wreckage of the nineteenth century, it is also a statement and affirmation of modern, postcolonial citizenship. The work of a disciple, it is nevertheless one that - between the lines - critiques the unequivocal, idealistic and absolute positions of its antecedents, and shifts openly away from the discursive burden of the past. 'I was thinking of Gandhi's natural rejection of the machine,' Anand remembered of the final, dark years before Independence. 'I wanted to show that, though we can't reject the machine altogether, we have to control it, as a driver controls a railway engine. ${ }^{46}$ Anand envisages postwar, diplomatically nonaligned India as ceasing to veer between parley and parry with the West, between embrace and rejection of the metropolis. Instead, it will follow an independent path of inquiry.

${ }^{42}$ Rama Jha, 'The Influence of Gandhian Thought on Indo-Anglian Novelists of the Thirties and Forties',

Journal of South Asian Literature, 16, 2 (1981), 163-172 (p.168); Mulk Raj Anand, Author to Critic: the Letters

of Mulk Raj Anand, ed. by Saros Cowasjee (Calcutta: Writers Workshop, 1973), p.52.

${ }^{43}$ Mulk Raj Anand, Conversations in Bloomsbury (Delhi: Oxford University Press, 1995), pp.51, 116.

${ }^{44}$ Mulk Raj Anand, Untouchable (London: Penguin, 1940), p.156.

${ }^{45}$ Mulk Raj Anand, Letters on India (London: George Routledge \& Sons, 1942), pp.152-158.

${ }^{46}$ Anand, Author, p.123. 